\title{
From sharecropping to equal shares: transforming the sharing economy in northeastern Brazil
}

\section{Jonathan DeVore ${ }^{1}$}

Published online: 9 August 2020

(C) Springer Nature B.V. 2020

\begin{abstract}
Concepts of sharing and commons are normatively and historically ambivalent. Some forms of sharing, such as sharecropping or alms-giving, proceed from and sustain asymmetrical relations to the means of life. Access to commons in other social contexts merely serves to make unequal forms of life more bearable. In other words, some expressions of sharing and commons are "functional" within hierarchical societies. Departing from these observations, this contribution traces contests over the logic of sharing, and apportioned shares of common land, from Brazil's slave period through contemporary land rights movements in the northeastern state of Bahia. For former slaves and their descendants, "freedom" often meant sharecropping on the same plantations from which they had been released. However, rural Brazilians have also succeeded in transforming shared land into more equal and equitable distributions, from "peasant breaches" that emerged in slave gardens from the early colonial period through the abolition of slavery, to land occupations that occurred in the late twentieth century. By sharing land and other material resources-especially tree seeds, seedlings, and cuttings - rural laborers have established unexpected reconfigurations in distributions of property and social recognition that exceed institutionalized norms of sharing common land. With such outcomes in view, this contribution distinguishes socially replicative and transformative sharing.
\end{abstract}

Keywords Sharing economy $\cdot$ Land rights $\cdot$ Property democratization $\cdot$ Post-slavery $\cdot$ Brazil

\section{Introduction}

Ongoing economic restructuring, new enclosures, and the erosion of social protections into the twenty-first century continue to sunder people's access to and control over means for

Jonathan DeVore

devorejd@miamioh.edu

1 Department of Anthropology, Department of Global \& Intercultural Studies, Miami University, Oxford, OH 45056, USA 
sustaining life (Bartels 2008; Orser 2012). Meanwhile, the means of life themselves are threatened by the undeniable consequences of climate change, and the looming specter of the infelicitously named "Anthropocene" (see Malm and Hornborg 2014; Moore 2017, 2018). ${ }^{1}$ These circumstances compel us to reexamine old and new forms of distribution, while reconsidering our relation to the means of life as mere means; for that upon which we are radically dependent can hardly be mere. As we rethink key concepts and ideas, the familiar and well-worn political antinomies of the past century (e.g., individualism and collectivism, private and collective property) will no longer serve us (DeVore 2017b); that ideological field of correlated but apparently opposed concepts served parallel logics of accumulation over the twentieth century that contributed to the destruction of human and other nature (Foster 2015).

As we reconstruct core political practices and institutions, concepts such as sharing and commons have become catchwords among activists, while drawing renewed attention among scholars (Benkler 2004; Helfrich and Bollier 2015; Widlok 2017). The so-called sharing economy has become especially important as the majority of the world's human population now lives in condensed urban and peri-urban areas, where the finitude of human lives and lifeworlds becomes strikingly evident. Innumerable smartphone apps enable people to share rides, appliances, housing, baby clothes, labor, and so forth. These sharing economies give new life to the circulation of old things, help renews bonds of trust, and foster economies of care. At the same time, however, the rise of the sharing economy can also be viewed as a mark of diminishing incomes and the neoliberal dismantling of the welfare state (Cockayne 2016; Martin 2016; Morton 2018), such that "much of what goes under the label sharing economy is in fact not sharing at all," but rather a "euphemism" for and "mystification of commercial market relations" (Widlok 2017:140).

These brief remarks suggest that concepts of sharing and commons are normatively and historically ambivalent apart from their historical specifications in social practice, with varied emancipatory outcomes. In a classic piece on egalitarianism among East African foraging societies, Woodburn characterized norms of sharing as preventing the emergence of social inequalities through foreclosure on saving, investment, and accumulation. In such contexts, sharing had the effect of "disengage[ing] people from property, [and] from the potentiality in property rights for creating dependency" (Woodburn 1982:445). Sharing was thus one among several political tools - a "levelling mechanism" (Widlok 2005) - that people in these communities could employ to either flatten or otherwise prevent the emergence of social hierarchies.

In societies where property is a salient and organizing principle, by contrast, sharing may occur among those with unequal access to, and control over, means of life. The English commons that were enclosed over the sixteenth and eighteenth centuries were, indeed, functional aspects of larger manor systems and integral to feudal society. The practice of "gleaning," for example, involved common rights that supervened upon, but did not cancel, the titles of feudal lords. While commoners sometimes violently defended the common "usages" that made life for them bearable (Thompson 1993), these same social arrangements - viewed within their larger context - helped to sustain the lives of the commoners' counterpart, the English aristocracy. John Locke variously described England's

\footnotetext{
${ }^{1}$ The COVID-19 pandemic emerged shortly after the original manuscript for this article was submitted in January 2020. The profound economic consequences of the pandemic have intensified debates about redistributive justice. This is a topic that I am currently pursuing in another manuscript, which draws on emerging evidence from the pandemic in Brazil to develop arguments about resilience and distributive politics that I have made elsewhere (DeVore 2016, 2019).
} 
aristocrats as "lazy and indigent people," whose "debauchery" and "expensive vanity" led them to "waste" resources through "extravagant expenses" (Locke 1824[1691]:53, 71-73, cited in Ashcraft 1986:268). In feudal Russia, in the years leading up to (and even after) the 1861 Emancipation Edict, the "commune" (mir, obshchina) system of land ownership similarly served to make life bearable for serfs and peasants who were subject to numerous forms of extraction by Russia's landed elites (Waldron 2007:61), while the commune organization itself served as a vehicle through which up to one-third of their production was extracted (Moon 1999:77). ${ }^{2}$ Commons and communes in such contexts, in other words, were not separate from the world of feudal lords and aristocrats; commons were rather a reflection of, and embedded within, an unequal and hierarchical society.

In such sociohistorical contexts, and in stark contrast with the kind of sharing economy described by Woodburn, sharing and commons both proceeded from and reaffirmed differences between society's "haves" and "have-nots." It was for reasons such as these that Immanuel Kant - who was so thoroughly invested in the Enlightenment project of exploding hierarchically ascribed status distinctions - was opposed to alms-giving. Giving alms and charity reflected and reproduced the hierarchical status of giver and receiver, meanwhile sustaining the distinction between them (Allais 2015, cited in Ferguson 2015:195, 226-227; cf. Sypnowich 2006). Along these lines, I consider this kind of sharing replicative sharing, insofar as it tends to replicate (or reproduce) the form of society from which it arises. By contrast with forms of sharing that merely reproduced unequal societies, Kant instead endorsed the gradual leveling of status distinctions, such that the difference between what he characterized as "active" and "passive" citizens would eventually dissolve (Kant 1999[1797]:119_ 121; see Ladd 1999:xlviii-xlix). This leveling could occur through state-led reforms designed to redistribute those material goods and resources necessary for their active inclusion in the citizenry (Dodson 2003). Along these lines, I consider this kind of sharing transformative sharing, insofar as it tends to transform (or reconstruct) the form of society from which it arises. ${ }^{3}$ Different logics of sharing thus either presuppose or entail different visions of society and the good, producing different outcomes for distributive and recognitive justice. For this reason, as I suggested above, concepts of sharing and commons are ambivalent apart from their historical and institutional specifications.

But it is also not enough to look to institutional specifications of sharing or commons, for those explicit logics are not coextensive with the full range of unanticipated consequences that may emerge from experimental or even routinized patterns of sharing, whether in actual or historical social practice. Some forms of sharing may be unexpectedly replicative, while others may be surprisingly transformative. In this contribution, I explore unexpected social

\footnotetext{
${ }^{2}$ In the important volume, Late Marx and the Russian Road, Teodor Shanin (1983) cites an editorial in a journal published by the Social Revolutionary Party of the People's Will, which describes the decadence of the mir in 1879: "Such too is the situation of the mir. For what purpose does the mir, the obshchina, exist? With what does it concern itself? Supplying recruits, collecting taxes, recovering arrears, forwarding contributions in kind-that is the life of the mir. And just as the peasant loses his individuality in an enforced pursuit of the rouble, so too does the obshchina lose its identity and become distorted, stifled by the regime in this sphere of exclusively fiscal and police obligations" (cited in Shanin 1983:220-221).

3 The distinction I suggest between "replicative" and "transformative" sharing is broadly informed by Nancy Fraser's (1995) distinction between "affirmative" and "transformative" distributive politics, which I have recently employed elsewhere to explore the transformative potentials of conditional cash transfer programs and redistributive land reform politics in Brazil (DeVore 2019). I would prefer the term "reproductive" instead of "replicative"; however, the former term carries unintended connotations in gender ideologies that associate women's labor with reproductive labor.
} 
consequences that occurred internal to sharing economies in the northeastern Brazilian state of Bahia, drawing analytic insight from G.W.F. Hegel's (1977[1807]) critique of feudal property relations in the Phenomenology of Spirit. In the few paragraphs on the so-called dialectic of "Lordship and Bondage," Hegel draws our attention to ways that the routinized performance of social hierarchy, and asymmetrical distributions of property and personhood, may activate critical normative intuitions about self, society, and justice. I elaborate this theoretical framework further below after describing the ethnographic and historical context in Brazil. In my presentation and analysis of the evidence, I focus on plots of land on the margins of Brazilian plantations, in provision grounds called roças. In such provision grounds, and across historical contexts, enslaved Africans prior to 1888 and free plantation laborers throughout the twentieth century were permitted to cultivate garden crops for their own subsistence - and sometimes sale in local markets. Such provision grounds bear a "family resemblance," in Wittgenstein's (1953) sense, to feudal commons briefly described above, as they are embedded within larger landholdings and productive arrangements that make life bearable for commoners but are otherwise controlled by social elites. Beyond shared land, however, I also focus on other economies of shared seeds, labor, and even car rides, which were substantially reconfigured as land rights organizations that emerged in Bahia in the 1990s directly challenged the asymmetrical distribution of land.

\section{Ethnographic and historical context}

This contribution draws on long-term field research with diverse land rights movements in the cacao zone along the southern coast of Bahia, Brazil, which appeared in the 1990s near the rural towns of Ituberá and Camamu (see Fig. 1). These social movements express broader, multigenerational struggles to overcome the enduring legacies of chattel slavery and the reinscription of bondage - or what some rural Brazilians call "captivity" (cativeiro) (DeVore 2014:366-367, 534-535) - to wage labor in the decades following legal emancipation after 1888. The historical arc of this research ranges from a reconstruction of the post-emancipation lifeworld built by poor rural families in this region's hills, followed by violent land grabs and dispossessions that forced these families back to plantation life and labor between the 1950s and 1970s. The story culminates with a surge of land occupations that occurred in the region between the late 1980s and 1990s.

One key limitation that freed slaves faced in Brazil's post-emancipation period involved the asymmetrical distribution of land, which favored an elite class of large property owners. Because of the maldistribution of land, many former and legally freed slaves were compelled to work as wages laborers and sharecroppers, often on the same plantations from which they had been released (Fraga Filho 2016; Mahony 1996). Those families that refused plantation labor, however, took to the forests and hills of southern Bahia, including the municipalities of Ituberá and Camamu, where they sought to reconstruct their lives (Fraga Filho 2016:101). Since 2002, I have been conducting ethnographic and ethnohistorical research in this region, totaling 38 months of fieldwork. On the basis of oral histories, I sought to reconstruct the lives of the free families inhabiting the region's forests and hills prior to the 1950s (DeVore 2014:26-293), which complements earlier and more recent research by other scholars who help develop a fuller picture of the region's history (Flesher 2006; Rocha da Silva 2018).

Historically, this region exhibited both the physical and social characteristics of what Scott (2009) calls a "hill space," or what Beltrán (1979) described as a "region of refuge." Dense 


\section{AREAS OF CACAO PRODUCTION BAHIA, BRAZIL (c.1948)}

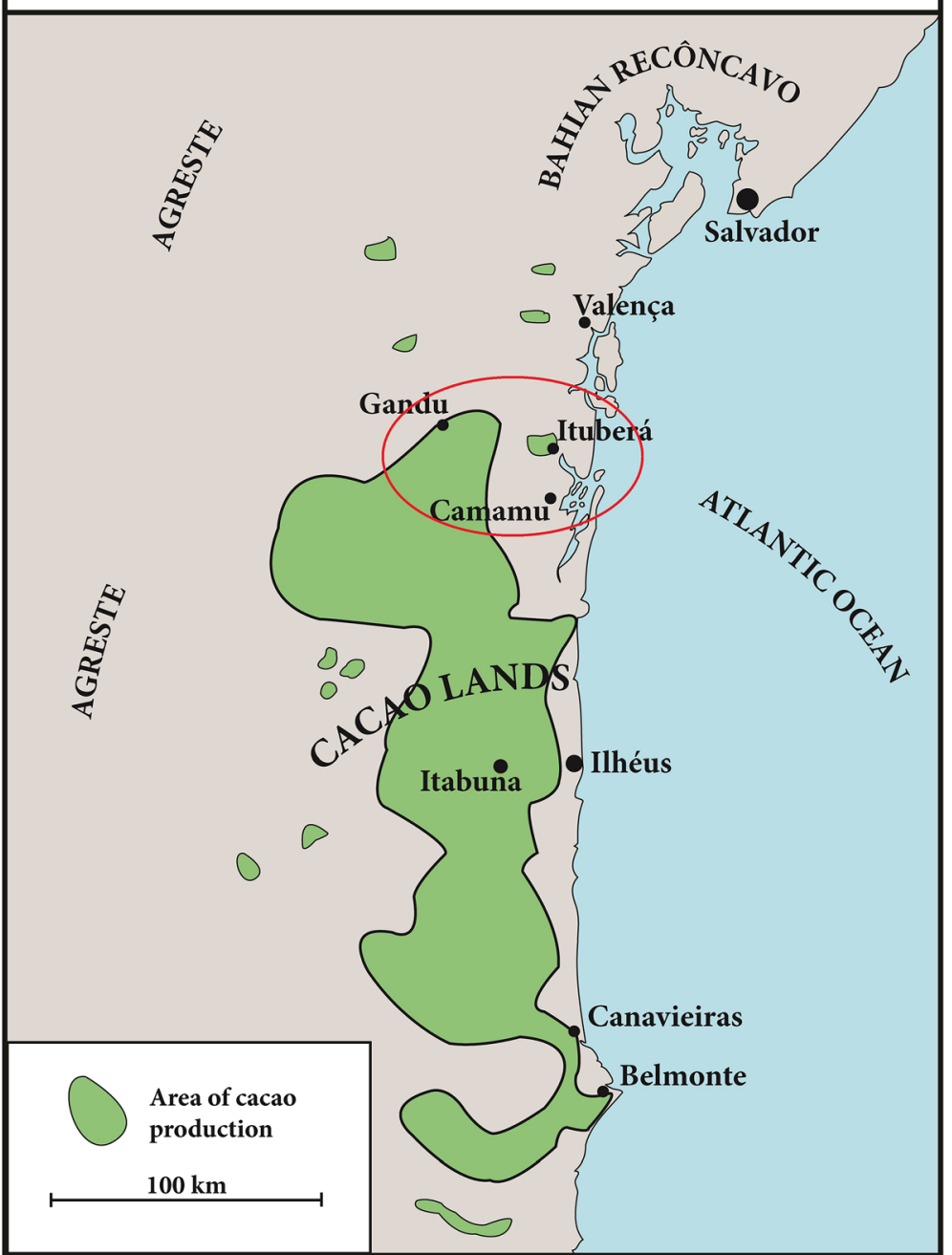

Fig. 1 Extent of Bahia's cacao zone circa 1948. Study area circumscribed in red. Adapted from Leeds (1957:37) and Tosta Filho (1948)

forest cover, heavy rainfall, steep hills, and waterways with limited navigability, historically converged to forestall the emergence of a robust plantation economy in this micro-region. Indeed, earlier in the nineteenth century, this region was home to escaped slaves who formed mocambo or quilombo communities (Schwartz 1992:104-109). In the decades following abolition, freed slaves, their families, and other members of the rural poor built a social world in these hills characterized by democratized control over land and an ethos of mutual aid (DeVore 2014:77-158). They succeeded, at least in some measure, in creating a world apart from the forms of subjection and coercive dependency that persisted on plantations elsewhere in Bahia. 
In the post-war period from the 1950s through the 1970s, however, these families were subjected to processes of "primitive accumulation" (Marx 1976[1867]), or "accumulation by dispossession" (Harvey 2003), as plantation capital encroached on the region. Families living in the hills were forcibly removed from the land, their houses were burned, and they either departed for hinterlands elsewhere, or else turned to wage labor on plantations that were being established in the region. One of Brazil's most infamous capitalists, the late Norberto Odebrecht (1920-2014), was a key player in dispossessing local families and helping to establish new rubber and cacao plantations by the 1970s (DeVore 2017a, 2018).

By the 1990s, however, the land claims of local plantation owners were contested by land rights movements that emerged in the wake of a fungal disease that was introduced to the region in the late 1980s (Pereira et al. 1989) — a witch's broom fungus (Crinipellis perniciosa) that devastated the cacao plantations. Plantation laborers who were laid off as a result of this crisis joined together and formed diverse land rights organizations. These included decentralized squatter organizations formed by former plantation laborers who occupied abandoned plantation lands; independent associations that sought to directly purchase plantation lands from former owners; and Brazil's internationally known social movement, the Landless Rural Workers' Movement, or MST. In the region around Ituberá and Camamu, these different groups occupied more than a half-dozen plantations (DeVore 2014, 2015).

This history points to a broad, multigenerational struggle for emancipation and economic freedom that was occurring well before, and long after, the culmination of legal emancipation in Brazil in 1888. Emancipation was not a legislative act (or even a collection of legislative acts in Brazil's case), but a long and abiding labor on the various material and symbolic conditions of people's lives. One of the sites for this ongoing work of emancipation has proceeded through the reconstruction of a sharing economy in which mere access replicated and reaffirmed social hierarchies that were grounded in asymmetrical distributions of land ownership. Across historical periods, tensions that emerged internal to hierarchical arrangements of land sharing gave rise to unexpected reconfigurations in distributions of property and personhood, pointing toward possibilities of sharing on a more equal footing. In the following sections, I characterize ways that sharing land was both functional within, and replicative of, plantation hierarchies, while simultaneously bringing about unanticipated leveling effects.

\section{Peasant breaches in the slave economy}

From the sixteenth century through the abolition of slavery in 1888, it was common practice in Brazil, and indeed throughout the Americas, for slave-owning planters to provide their slaves with plots of land where they could grow their own food provisions (Berlin and Morgan 1991; Genovese 1974:535-540; Schwartz 1992:49-55). These plots, referred to as roças in Brazil, were usually located on marginal plantation lands where valuable cash crops, such as sugar or coffee, could not be profitably cultivated (Barickman 1994). The term roça derives from the verb roçar, which refers to the process of clearing and opening new plots of land for cultivation. Clearing a roça in southern Bahia involved difficult and dangerous work, as it meant felling large trees to clear small patches of forest. Some nineteenth century Bahian sugar planters suggested that provision grounds could obviate the need to provide sustenance for 
their enslaved labor force, with some planters suggesting that slaves should be given "a day instead of a ration" (Calmon 1834, cited in Barickman 1994:663, emphasis in original). ${ }^{4}$ By this expression, Calmon referred to planters who believed that slaves should be given a day off from plantation labor, usually on Sundays, to cultivate their own roças. In these plots, and under their own direction, enslaved families could plant subsistence crops such as beans, corn, various vegetables, and manioc. Manioc tubers were processed into a coarse flour, called farinha de mandioca, that was and remains a key component of rural Bahians' diets.

The purpose of providing slaves with land to plant for themselves was twofold, both functional and instrumental. In the first place, as these provision grounds permitted slaves to provide for their own subsistence, slave owners could reduce or eliminate the need to provide food rations to their slaves. For the planter class, provision grounds provided an economical way to cut costs and increase profits. The second rationale for providing slaves with provision grounds was ideological control (Silva 1989), which resonates with arguments about the disciplining effects of labor, and specifically the act of making objects for the enjoyment of others, elaborated in G.W.F. Hegel's dialectic of "Lordship and Bondage" (1977[1807]:118). As the nineteenth century planter Miguel Calmon noted:

[A] master should give his slave some property or make it easier for him to acquire some on his own and should encourage his industry. This is a powerful means of distracting him from the ideas that go hand in hand with his sad condition and of inspiring in him a desire to work and even of inviting him to form a family. The practice of encouraging him to plant a roça, especially with food crops, of allowing him to have some livestock or to exercise some trade - this without doubt will lead to his happiness since it can modify the unruly tendencies that slavery generates and fosters. [Calmon 1834:60, cited in Barickman 1994:681]

Calmon thought that providing slaves with plots of land, as well as the time to work for themselves, helped sustain the plantation as an enterprise while serving to replicate plantation society.

However, the disciplining effects of labor do not only reproduce the relationship between master and slave. The complex relation between labor, property, and emancipation is crystallized in Hegel's critique of German feudal society, which provided the historical backdrop for his famous account of landed "Lordship" (Grundherrschaft) and "Bondage" (or serfdom; Knechtschaft) (see Cole 2004) — the so-called master-slave dialectic. ${ }^{5}$ Hegel's core insight was that the routinized performance of roles institutionally ascribed to master and slave give rise to unintended, transformative, and emancipatory consequences, especially with respect to the slave's institutional status, as such. Whereas the master's orientation to the objects upon which the slave labors - which for the master were defined by their "simple sensuous qualities"was merely that of a "desiring-consuming subject" (Redding 2012:53), the slave's orientation to those same objects is mediated in several, more complex ways. First, to successfully produce the object, the slave cannot merely act on immediate impulse, but must defer any consumptive desires; second, she must act according to a concept of the thing she produces; third, her work on the object is socially mediated by the will of another, on whose behalf she

\footnotetext{
${ }^{4}$ Watkins (2015:35) points to textual reference in Soares de Sousa (1879[1587]) that trace such productive arrangements to the sixteenth century.

5 This intellectual tradition is currently undergoing significant reevaluation. Further exegetical work can be found in Brandom (2019:343-347), Redding (2012), and Waldron (1988:310-313, 371-374).
} 
acts (see Redding 2012:53-56). In short, the slave's lifeworld is far more multifaceted, complex, and socially developed than the profoundly impoverished worldview of the master. Analytic philosopher Paul Redding describes the consequences in the following way:

This mediation means that while the slave is addressed by the master as a slave, and so recognizes himself in that address as a slave, there are other relations that can contribute to the form of self-consciousness of which the slave is capable, relations that can allow the slave to recognize himself in ways that come into contradiction with his self-identity as a slave. [Redding 2012:55-56].

In other words, through her work, the slave grasp herself as something more than a "slave," as there are inferential (i.e., semiotic) consequences of her work that disrupt, contradict, and exceed the social status that is ascribed and available to her. The relationships in and through which people variously shape and transform the world activate latent normative intuitions about property, distributive justice, and social recognition; the seemingly lowly activity of laboring on things thus becomes a critical source for renewed self-awareness - along the path toward what Marx envisioned as a revolutionary society (see Taylor 1975:154-157)—with corrosive effects on asymmetrical (and institutionally sanctioned) distributions of property and personhood.

As an organization of labor, the consequences of provision grounds in Brazil were much further reaching than the purposes explicitly envisioned by Brazilian slave owners, leading to what historians and historically attentive anthropologists have described as a "peasant breach" in the institution of slavery itself (Cardoso 1979, 1988; see Barickman 1994; Mintz 1974; Schwartz 1977). ${ }^{6}$ Historians have examined postmortem estate inventories to infer consequences of the customary rights that emerged through the peasant breach. In the southern Recôncavo, just south of Salvador and north of Bahia's cacao zone, Barickman reported on an 1857 inventory that listed "a coffee grove that had once belonged to a slave named Joaquim ('outra porção de cafezeiros que foram do escravo Joaquim') with an appraised value of Rs.15\$000" (1994:661). In Bahia's cacao zone, Mahony cites an inventory dated to 1849, listing 84 cacao trees, ten years old at the time, as being "without value because they belonged to João, a slave on the fazenda [plantation]" (1996:350). These cases suggest that, through planting cacao and coffee trees, enslaved people such as João and Joaquim were able to create specifiable, legally recognizable, and defensible property rights on land that was shared with them by plantation owners. Independent of the slave owners' intended purposes, enslaved Brazilians were able to create and stabilize shares of their own that garnered both de facto social recognition and later de jure, legal recognition. These social facts, proceeding from cultivated roças, militated against slaves' legal and institutional roles as mere property objects. Having secured small spaces of autonomy within the plantation landscape, and opportunities to accumulate small bits of wealth for themselves, these peasant breaches even helped some slaves to achieve their freedom through "self-purchase."7

Whereas in the cases described by Woodburn, sharing had both the purpose and effect of dissolving social hierarchies by foreclosing opportunities to generate and accumulate property, in southern Bahia, slave owners' decisions to provide slaves with plots of land they could cultivate for themselves had a similar (if incipient) effect on dissolving social hierarchies. By contrast with the context that Woodburn described, however, this leveling effect operated

\footnotetext{
${ }^{6}$ Bert J. Barickman (1991:162-182 and 1994) provides an extensive review of the literature for Bahia.

${ }^{7}$ Like the peasant breach, manumission through self-purchase was another "customary right blacks had wrested from their masters" (Chalhoub 1989:70-71).
} 
through a generalized opportunity to generate and accumulate property among slaves, who were otherwise the objects of others' claims to ownership and mastery. By accumulating property for themselves, slaves could contest and subvert the property claims of their masters. In other words, the customary practice of sharing marginal plots of plantation land with enslaved laborers brought about gradual and subtle internal reconfigurations within Bahia's plantation and slave economy. In Slavery and Social Death, Orlando Patterson (1982:28) wrote the following about slaves in societies where the "personalistic idiom" of slavery was predominant: "the slave was a slave not because he was the object of property, but because he could not be the subject of property." In Brazil, enslaved people demonstrated that they were more than mere objects of others' property, precisely through their emergence as subjects of property. This was hardly an intended outcome of this particular institution of land sharing, at least as it was conceived by the class of slave-owning planters in Brazil.

\section{Peasant breaches after legal emancipation}

In the post-emancipation period after 1888, and throughout the twentieth century, it remained a common practice for Brazilian planters to permit free wage laborers to cultivate provision grounds on plantation properties, which continued to be referred to as "roças." As before, these provision grounds mingled workers' interests with those of the plantation owners and managers. On the rubber and cacao plantations that emerged near Ituberá and Camamu in the 1950s, plantation owners permitted workers to cultivate both subsistence and cash crops of their own on plantation lands, including beans, corn, manioc, and certain - but not allvarieties of bananas. ${ }^{8}$ For workers, manioc and bananas served the dual purpose of providing sustenance as well as potential cash flow through their sale in local markets. In return for access to these provision grounds, and after their crops were harvested, the workers would restore these plots of land to the landowners. In some agreements, workers had to either leave the land prepared for re-cultivation by the plantation, or else deliver their roças planted with cash crops that would belong to the plantation. In other words, workers' subsistence gardens had to eventually be converted into a form of living capital for the plantations, such as in the form of cacao groves or pasture grass.

These land-sharing arrangements benefitted workers and landowners in different ways. Workers could provide for their subsistence and sell any surplus on local markets. Landowners, on the other hand, received newly cultivated plots of land without expending any capital (e.g., in wages), as the costs of preparing land for cultivation, including the heavy work of clearing forest, were assumed entirely by the workers. In short, workers' labor was converted directly into productive capital for the plantation. These modern provision grounds thus amounted to a windfall for landowners, reproducing processes of labor extraction and capital accumulation, while ultimately leaving the asymmetrical distribution of capital in land intact. In other words, sharing plots of uncultivated land with workers served to replicate both plantation production and the asymmetrical form of society.

Certain forms of cultivation, however, were proscribed in these modern provision grounds. Above, I referred to the enslaved laborers, João and Joaquim, who held property in the cacao

\footnotetext{
${ }^{8}$ Some varieties of bananas (such as banana da prata) were prohibited, as these perennial varieties could become durable features of the biosocial landscape, constituting what is called a "root good" (bem de ráiz), as will be discussed below.
} 
and coffee trees that they planted on their masters' lands. In the twentieth century, rural workers who cultivated trees - rather than beans, manioc, or vegetables - or built any other durable infrastructure on plantation lands could similarly make claims to property rights that interfered with the rights of landowners. One young man named Silvano, a resident at a squatter community called Nossa Senhora, recalled this when he suggested that, at least historically, cacao planters prohibited workers from keeping any cacao seeds. These seeds could be used as instruments of "reverse" dispossession against the landowners - much like in the cases of the enslaved laborers, João and Joaquim. Against these prohibitions, Silvano explained, plantation workers could swallow handfuls of seeds while harvesting them from cacao pods and smuggle them out of the plantation in their bellies. After defecating the seeds, they could plant them in small cacao groves of their own, which one day might help the workers free themselves from plantation labor. Unlike beans and manioc, cacao and other trees formed a durable presence on the land where they were planted, and thus staked durable claims to the land itself upon which they persisted. For this reason, sharing and planting certain kinds of seeds was thus proscribed, as such seeds could threaten the distribution of property in land. In other words, sharing certain kinds of seeds threatened plantation production, and the asymmetrical form of society, by potentially freeing workers from their dependence on wage labor.

Nonetheless, the cultivation of other fruit trees could form part of a worker sharing economy within the plantation landscape. A plantation worker named Caio thought it was beneficial to cultivate fruit trees on plantation grounds, as these could form part of a sharing economy among workers residing on the plantations. When workers cultivated fruit trees near worker housing, Caio explained, then any and all future workers to inhabit such housing would share in an abundance of fruit for their subsistence. Planting fruit trees on plantation grounds thus amounted to an expression of solidarity among the workers themselves. A former plantation worker named Damião, now a squatter at Nossa Senhora, explained that jackfruit (Artocarpus heterophyllus) trees were a common resource that provided nourishment for people and many other organisms, he explained, as it benefits "me, a person doing odd jobs [fazendo bico], birds." Because such trees were a public good, Damião felt that it was "a crime to cut down a jackfruit tree." Despite their undeniable good, however, such common resources do not threaten the asymmetrical structure of society, but rather help to make life bearable for those on the margins. Indirectly, these forms of sharing help to replicate plantation production and plantation society.

As was already suggested above, however, the cultivation of certain kinds of durable tree crops posed risks for landowners. A man named Colodino, a former plantation worker who eventually settled at Nossa Senhora, explained that many plantation managers prohibit workers from cultivating any kind of tree varieties, as trees are what is commonly referred to as bens de raiz. The concept of a bem de raiz (singular; bens de raiz, plural) is an old term common to Portuguese and Brazilian jurisprudence, which literally translates as "root good." A root good refers to any form of immovable property (immóvel), and may include buildings, any improvements or additions to existing buildings, structures such as fences or drying ovens, or any other durable modification to the biophysical and built environment that is not (easily) moveable elsewhere. In southern Bahia, trees also count as root goods.

The expression "root good" has obvious botanical overtones, and in the language of rural families and plantation workers, root goods primarily refer to trees and other perennial plants. Manioc, although literally a root crop, is not a root good because its presence on the landscape is relatively fleeting and impermanent. Colodino explained that root goods may thus include things like: 
...fruit trees, jackfruit, cacao trees, avocado trees - they're all bem de raiz. So, they [plantation owners] worry that you'll have [rights to what you planted]-somehow or other, that plant is yours. It was planted by you, so they're obligated to compensate [indenizar] you. That's why they don't want [you to plant bem de raiz]. Because if you plant and demand it, they are obliged to pay.

In other words, if a worker (or squatter) plants trees on plantation land, and does so with their own labor, resources, time, and volition - rather than as part of a work agreement or contract with another landowner - then those trees become the personal private property of the person who planted them. ${ }^{9}$ Because such property is durable on the landscape, with roots literally entangled with another's property in land, landowners may either be required to compensate workers for those trees' monetary values, or else effectively cede their control of the land. ${ }^{10}$ As I have described elsewhere, this was precisely what happened with a woman named Alvina, who created property of her own by planting trees on land controlled by her miserly in-laws (DeVore 2018:512 and 2014:235-238, 563-566).

Shared space on plantation lands, consequently, was often limited by the kinds of things that could be safely cultivated, at least from the perspective of plantation owners. Less durable annual crops like beans, corn, tomatoes, and manioc could be safely cultivated, as the physical space to which their presence staked a de facto claim had a limited time horizon. Tree crops such as rubber or cacao, however, posed distinct risks as they threatened to convert the properties of large landowners into the properties of workers.

In the second half of the twentieth century, as occurred with the provision grounds owned by slaves, practical understandings about "root goods" were increasingly codified. Following the military coup in 1964, the Brazilian government passed a series of agrarian legal reforms that were meant to placate and demobilize the peasant leagues that were gaining momentum in northeastern Brazil (Pereira 1997). These reforms included the 1964 Land Statute (Estatuto da Terra), one effect of which was to bolster rural workers' ownership claims to any improvements or other durable modifications they made on the plantations where they resided and worked. ${ }^{11}$ In a study of workers' syndicates in the state of Rio de Janeiro, O'Dwyer (2008) suggested that the "Land Statute guarantees workers, who planted bens de raiz on garden plots [sitios] located on large properties, the [legal] condition of owner over the improvements made" (2008:237, my translation). Without proper indemnification, root goods could not be alienated from the workers who created them.

\footnotetext{
${ }^{9}$ Caio and Colodino make apparently contradictory claims. In their statements briefly examined above, Caio suggested that it both good and even commonplace for workers to plant fruit trees near worker housing, whereas Colodino suggested that plantation owners and managers generally prohibit the cultivation of any root goods. The difference probably lies in the degree to which different plantation owners and managers found it worthwhile to micromanage their properties, and to root out each and every clandestine grove. The key difference, however, probably lies in the negligible market value for tree fruits meant for immediate consumption in contrast with the market value of tree crops, such as cacao or cupuaçu.

${ }^{10}$ The possibility of losing control and ownership of one's property is related to another legal concept called "usucaption," which Brazilian civil law inherited from Roman civil law via the Portuguese, and is alive in local language. Usucaption is a form of "prescriptive acquisition" or "adverse possession." The Latin term usucapio (to capture, or take possession, by continuous use and enjoyment), or usucapião in Portuguese, is sometimes rendered by local squatter families as "usu-campeão," which could be translated as "use champions," analogous to victors in a soccer match. The cultivation of trees on another's land would provide evidence for continuous use and enjoyment necessary to win such a contest.

${ }^{11}$ Law No. 4.504 of November 30, 1964.
} 
The cultivation of durable trees, or any other root goods, reappeared as a legally codified action through which rural workers could make and stake property claims for themselves. Land sharing economies negotiated among plantation owners and laborers during and prior to the twentieth century thus exerted pressure on legal systems such that they aligned with noncodified social practice. For this reason, certain forms of land sharing were increasingly proscribed, as they threatened the overall distribution of access to and control over land. Sharing land with workers to plant beans, corn, and manioc made only minor concessions to, but ultimately reaffirmed, the unequal society. Planting trees or any other durable crop, however, threatened to destabilize (if not overthrow) the hierarchical edifice.

\section{From breaches to peasant occupations}

The land occupations that occurred between the mid-1980s and 1990s in Bahia's cacao zone amounted to an even more radical transformation of the region's political and moral economy. Instead of the gradual, and often implicit, transformations of land and property relations that occurred through different peasant breaches on plantation lands, the land rights organizations that emerged in the region at the end of the twentieth century made stronger and more direct claims to land of their own. As squatter organizations took up and occupied plots of land for themselves, their claims threatened the hierarchical social order, including previous forms of clientelistic social exchange that characterized relationships between plantation owners and workers. The claims advanced by different land rights organizations were thus met with violent reactions from local land-owning elites.

A former plantation called Angústia was one of the first to be occupied in the hills west of Ituberá and Camamu. The occupation there began in the mid- to late-1980s, and was protracted, conflicted, and violent. Damião, who participated in that occupation before eventually settling at Nossa Senhora, recalled the occupation: "A lot of people died there, lots of people died in that invasion. Gunmen killed lots of people, and the people killed lots of gunmen." A squatter at Angústia named Ulisses recalled the fear that he and his companions felt whenever they walked down rural roads in the early years of the occupation. "When we heard a car [approaching], we had to dive hidden into the bushes," for they feared the arrival of hired gunmen and thus for their lives (cf. DeVore 2014:624-634).

Honório, another squatter at Angústia, recalled that local landowners "treated us as invaders. They never offered rides to nobody...They wanted nothing to do with [não queria meia] with the people, not even to say 'good day." Honório's phrase, "they didn't want nothing to do with the people" (não queria meia com o povo) initially refers to the denial of social recognition, such as in the refusal to say "good day" (bom dia). But the phrase "nothing to do," from the Portuguese expression não querer meia, is more accurately translated as "they didn't want half" or a "share" with the people, as the term meia also recalls the practice of sharecropping (produçao de meia). Thus, it is significant that Honório mentions landowners' collective refusal to offer people rides, or what is referred to as a carona in Brazil.

Ride-sharing between rural workers and vehicle-owning landowners is a common manifestation of clientelistic social exchange in Bahia's cacao zone, and throughout Brazil more generally. Ride-sharing is an asymmetrical form of exchange, a favor that cannot be returned, insofar as many (if not most) landless rural workers do not own vehicles of their own, and thus lack opportunities to reciprocate. Although these asymmetrical acts of ride sharing cannot be reciprocated, a return can nonetheless be achieved by expressing deference to and esteem for 
the person who gave the ride. Reminding others of one's previous acts of ride sharing, and calling attention to one's generosity, can be used to make those others humble - to humiliate them. ${ }^{12}$ Ride sharing can thus express hierarchized and asymmetrical forms of social recognition. Similarly, a woman named Joana, a squatter at Nossa Senhora, recalled that before her family secured land of their own, she used to steal bananas and other fruits from neighboring plantations, just to feed her family. On one occasion, she was caught by a plantation manager just as she was cutting down a banana tree. Rather than punishing her, the plantation manager simply stated: "just make sure it [the banana tree] doesn't fall on cacao trees." The manager appropriated and transformed her act of theft into an act that expressed his magnanimity and generosity, leaving her humiliated and feeling the "greatest shame" (maior vergonha), as she recalled the episode.

Thus, the fact that Ulisses and his companions had to hide from passing cars, for fear of impending violence, and that local landowners refused them social recognition or other traditional forms of exchange, as Honório explained, indicates that the clientelistic sharing economy, at least as it was known formerly, was irrevocably transformed by these land occupations. The former exchange of clientelist favors - that replicated the asymmetrical distribution of material goods and social recognition-burst into relations of increasing enmity, hostility, and occasional violence. As the squatters established themselves as a durable presence on the social landscape, however, new and unexpected sharing and other exchange relations began to emerge, as former parties to patron-client relations faced each other on a more equal footing.

\section{A reconstructed sharing economy}

Following the land occupations that culminated in the late 1990s, new sharing economies emerged among families in local squatter and land reform communities. When the tumult of the initial occupations began to calm, and the squatters divided and distributed equal shares of land to each family (DeVore 2015:1215-1216), they continued the work of reconstructing their social world. Some of these efforts included work to transform forests into agroforests (DeVore 2017b), the construction of new homes, as well as work on new infrastructure to distribute goods and services such as water and electricity (DeVore 2017c). These diverse labors occasioned a manifold sharing economy, where people share labor, time, and various other resources that were part of wider processes of social reconstruction.

The processes of converting forest into agroforest, in particular, brought intensified demand for seeds, seedlings, cuttings, and other plant materials. The trees and other plants cultivated in these agroforests included a broad range of cash and subsistence crops, such as rubber, cacao, cupuaçu, guaraná, graviola, clove, black pepper, bananas, manioc, and numerous garden crops - and even native tree species (see DeVore et al. 2019). Demand for these various trees

\footnotetext{
${ }^{12}$ I learned this the hard way sometime in 2003 or 2004 while walking down a country road, when a white man driving a large truck stopped and offered me a ride to my destination. I had never met him before, and had no idea who he was. Sometime later, I encountered him again in the town square. Although I remembered his face, I could not recall where we had previously met. The man appeared offended and reminded me that he had given me a ride several months prior. Later, I realized that he was not offended by the fact that I had forgotten the specific context within which we had met, but rather that I did not remember him, who he was, and what he represented to local society. I later learned that he was a member of one of the region's political elite families. By forgetting who he was, I had failed to honor him.
} 
and other plants gave rise to a seed- and plant-sharing economy, as different botanical resources changed hands through tiny gestures, often with few formalities, among families, friends, neighbors, and even strangers. This sharing economy can be seen in different stages of the long-term projects to cultivate agroforests. People clearing new roças from patches of forest might share excess cellulose (e.g., firewood) with neighbors, or trade good pieces of timber for finished wood products (e.g., doors, windows) with which they might outfit their new houses. Cultivating newly opened roças required seeds and seedlings, and eventually plant cuttings for grafting material. Over time, plant materials that were secured by various means, including sharing, would later become sources of seeds, seedlings, and cuttings that could be shared more widely. For example, manioc is cultivated from cuttings derived from the stems of harvested manioc plants. These cuttings, or mandibas as they are called, grow into new manioc plants when inserted into the ground (see Fig. 2). When harvested, the discarded stems of mature manioc plants are a source of more mandibas that can be shared with yet others who are preparing to cultivate new manioc gardens of their own. Special and rare varieties of bananas are sought after with interest, with banana rhizomes being shared and sometimes traded like collectibles (see Fig. 3). These bananas provide shade for young cacao trees, the seeds for which may come from cacao pods that were shared among friends and neighbors seeking to establish tree nurseries of their own (see Fig. 4). Rubber tree seeds can be collected freely along roadsides - a de facto commons - where rubber trees deposit large quantities of seeds at certain times of the year. Cuttings from rose bushes, orchids growing on the sides of trees, and various herbal and medicinal plants are shared and transplanted across farms and among households. Seeds and cuttings from various fruits trees, or cuttings from the branches of improved varieties of cacao or rubber, are shared among households and grafted into young trees already growing in their gardens and orchards (see Fig. 5). Novel tree and fruits, such as rambutans and mangosteens, circulate as people's palates adjust to new flavors, and new niche markets grow.

The democratization property in land, and the generalized distribution of plants, also led to novel expressions of land sharing and sharecropping. One particular squatter at Nossa Senhora named Galeno bought a flatbed truck and began buying banana harvests from neighboring squatter families, which he then resold for a profit at a regional market in a town called Wenceslau Guimarães. To foster these market activities, Galeno readily provided labor from his own family, and banana rhizomes from his own farm, to help other squatter families establish banana groves that would eventually provide shade for young cacao and rubber trees of their own. As a local buyer, Galeno had a clear interest in offering plants and labor to other squatters, as he would later buy their banana harvests. But he provided these resources free of any cost, articulating an ethos of solidarity by emphasizing the importance of "giving" (dar) and "donating" (doar) such resources to people of humble origins, like himself. By contrast, he emphasized that the "rich" could and should pay for such things. Unlike other forms of sharecropping described in previous sections, however, Galeno helped these local families establish cacao and rubber groves of their own-effectively helping them to creating durable (re)productive capital and capacities of their own. The squatter families with whom Galeno did business began as havenots, in possession of land that they barely had the resources to cultivate by themselves. These families ended with land cultivated in productive and durable agroforests. Thus, although he had a clear personal interest in sharing labor, plants, and other resources with neighboring squatters, Galeno also helped to close the resource gap between his own and other families, rather than reaffirming the difference that characterized their starting 


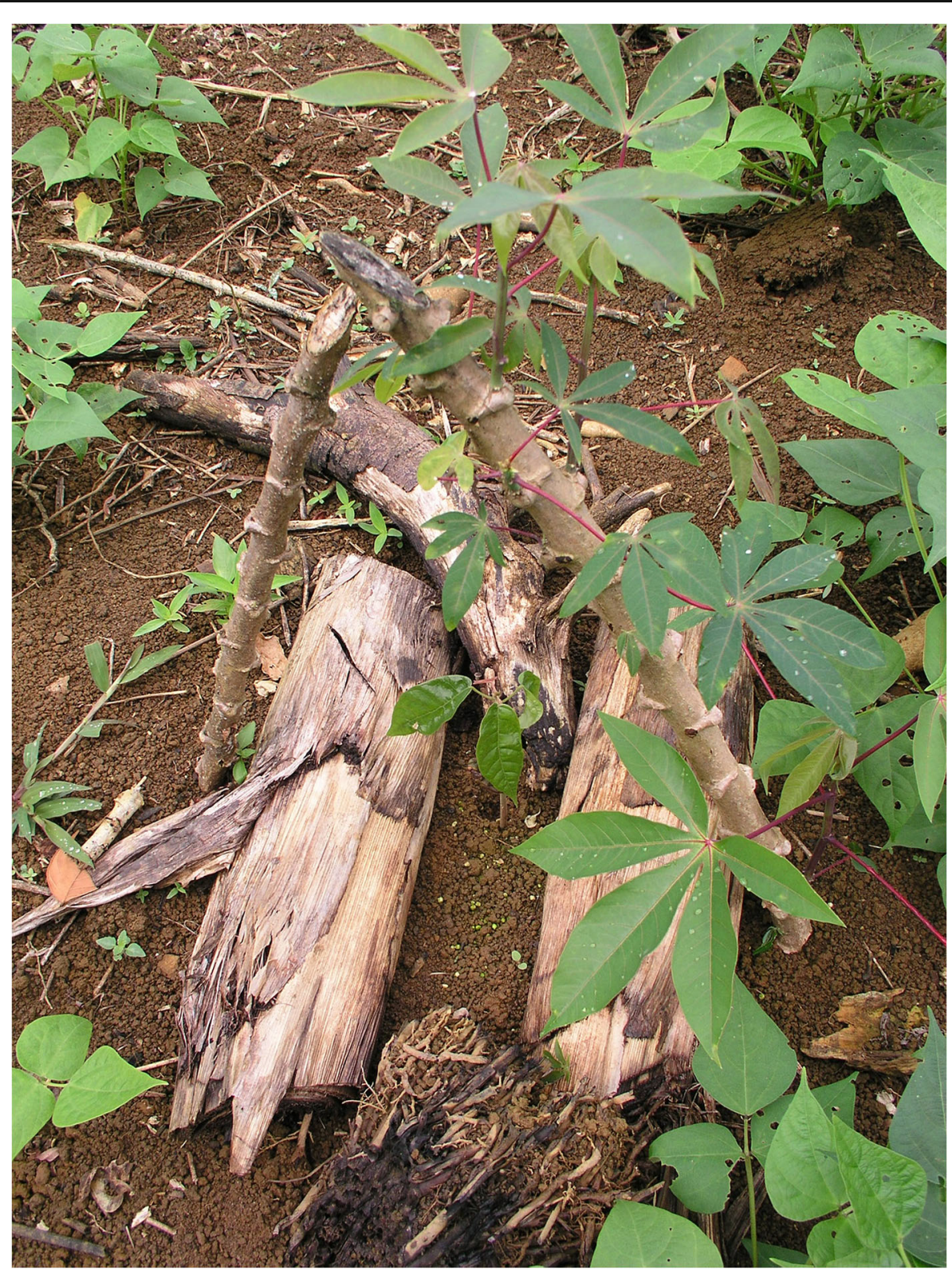

Fig. 2 Two mandibas stuck into the dirt, sprouting into young manioc plants. March 30, 2004. Photo by Jonathan DeVore

points, as haves and have-nots. This form of sharing was transformative, rather than replicating the initial difference between Galeno and other squatters.

Another significant development arose in the previously asymmetrical exchanges between plantation owners and former plantation laborers who became squatters. By contrast to the enmity and violence that initially characterized relations between landowners and squatters following the land occupations, a sharing economy has gradually emerged over the years 


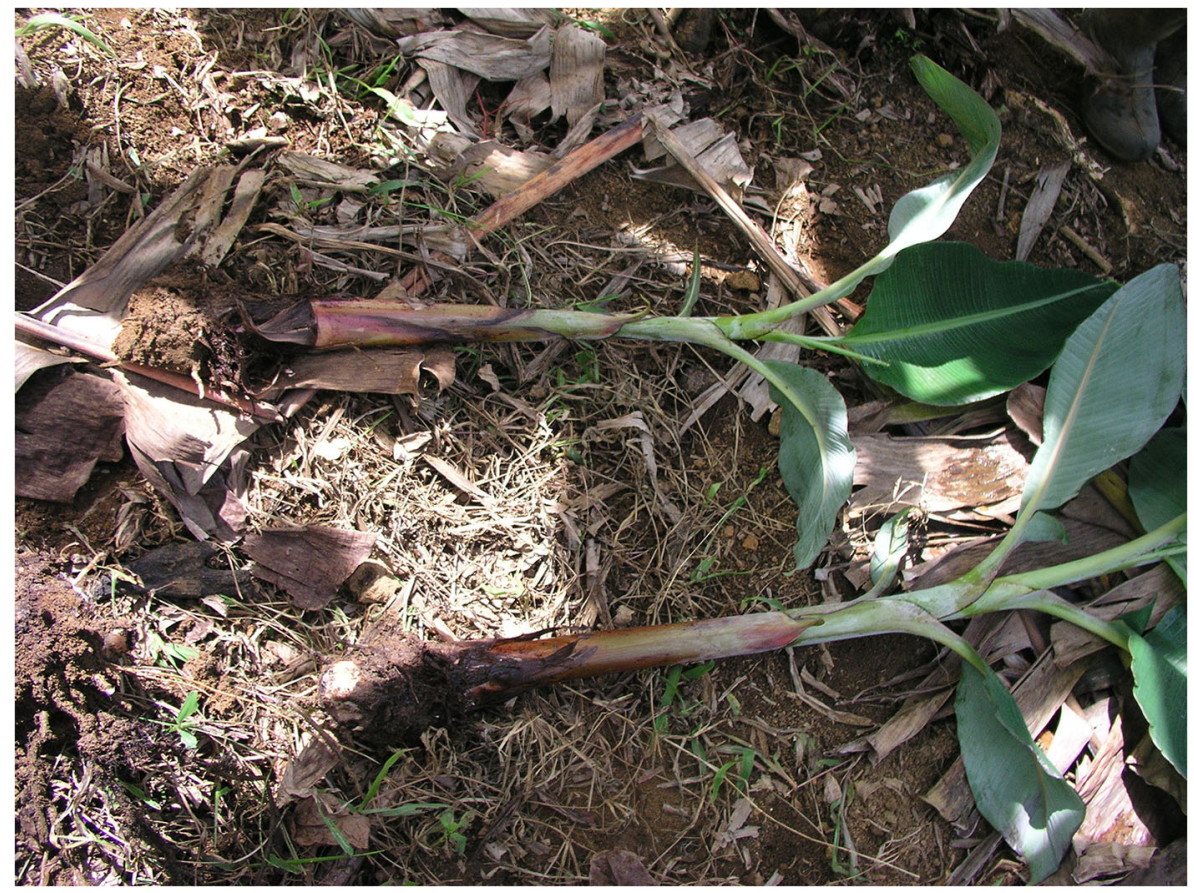

Fig. 3 Young banana rhizomes from a farm at the squatter settlement Nossa Senhora. March 30, 2004. Photo by Jonathan DeVore

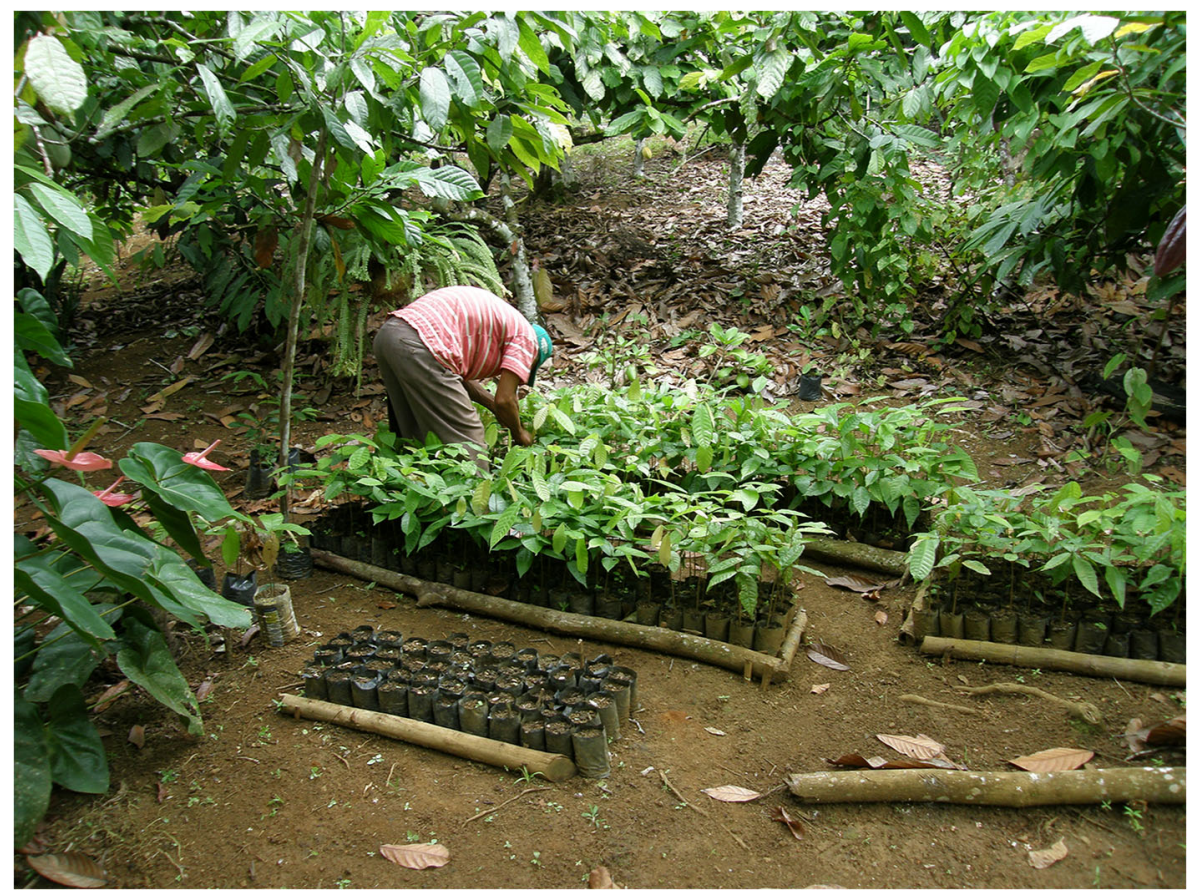

Fig. 4 A squatter at Casa Nova tending to young cacao seedlings. May 17, 2012. Photo by Jonathan DeVore 


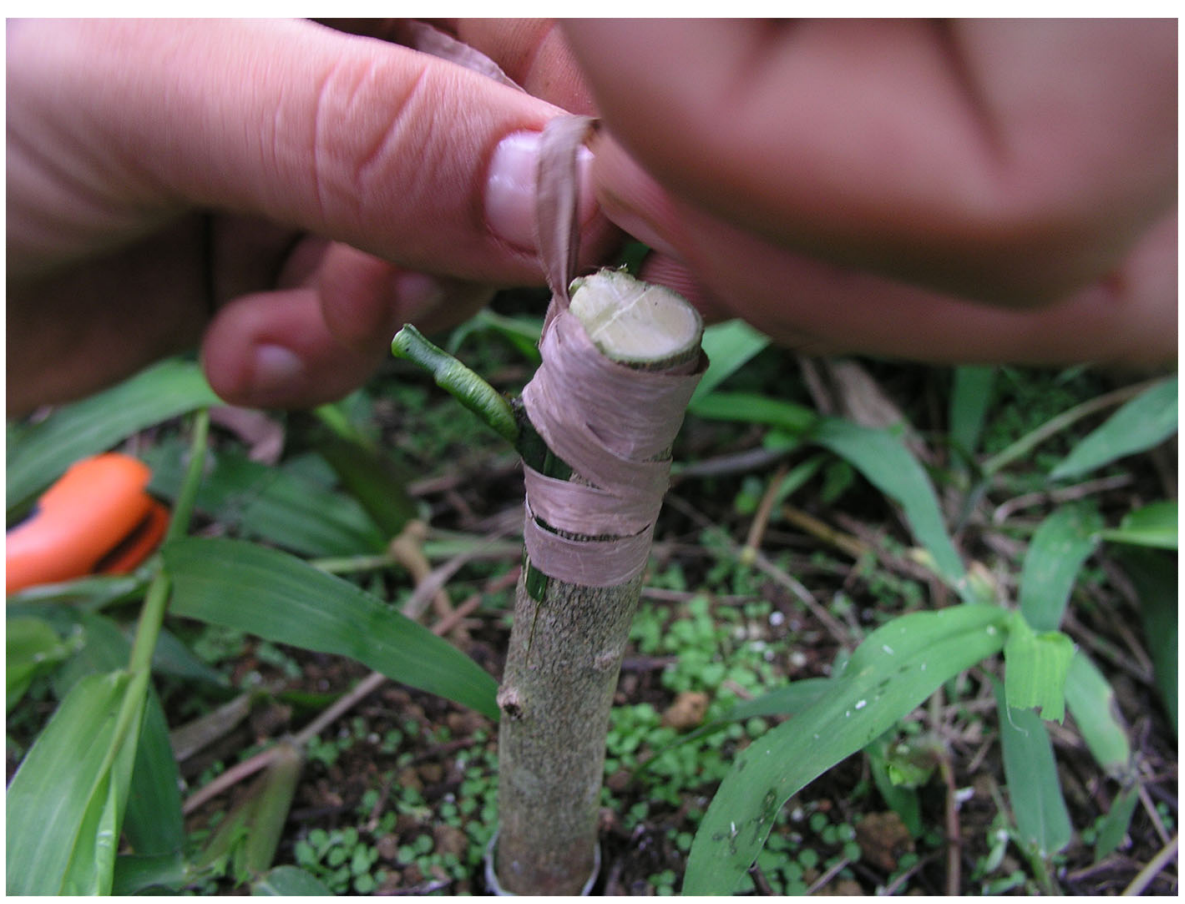

Fig. 5 Grafting together different varieties of lime trees. January 19, 2004. Photo by Jonathan DeVore

between these formerly opposed parties. Not only have "good days" and ride-sharing (caronas) returned to squatters, many of whom continue to travel by foot, but now some plantation managers even offer tractors, trailers, and other plantation vehicles to help squatters achieve larger purposes. On one occasion, for example, a plantation manager helped one family move their personal belongings and furniture from a former dwelling in a community called Pequi to a new house that the family built on their farm (see Fig. 6). On another occasion, a plantation manager helped another family transport large steel plates to their farm, which were crucial bits of infrastructure used to build drying ovens for cacao and other products. The kinds of ride-sharing offered by plantation managers not only helped squatter families get from point A to point B but also participated directly in squatters' efforts to transform the material conditions of their lives.

Through cultivation processes, moreover, further exchanges have appeared between squatter communities and their neighboring plantations. Some plantation managers freely offer plant cuttings and grafting material from improved varieties of cacao and rubber, which have been bred for increased productivity and disease resistance. Like the rare and special banana varieties, squatters collect diverse clone material that they graft into the rubber and cacao trees growing on their own roças. Although squatters may have materially less to share in return, the sharing economy goes both ways. Squatters may offer surplus from their fruit harvests with plantation workers and managers alike. Some may collaborate on shared infrastructure projects, such as road maintenance, or share excess firewood from their recently cleared roças. Some young (environmentally conscious) squatters, more recently, have supported efforts by local plantations to plant native tree species on their landholdings, gathering and delivering tree seeds that grow on and around their own farms. Figure 7 summarizes 50 acts of sharing 


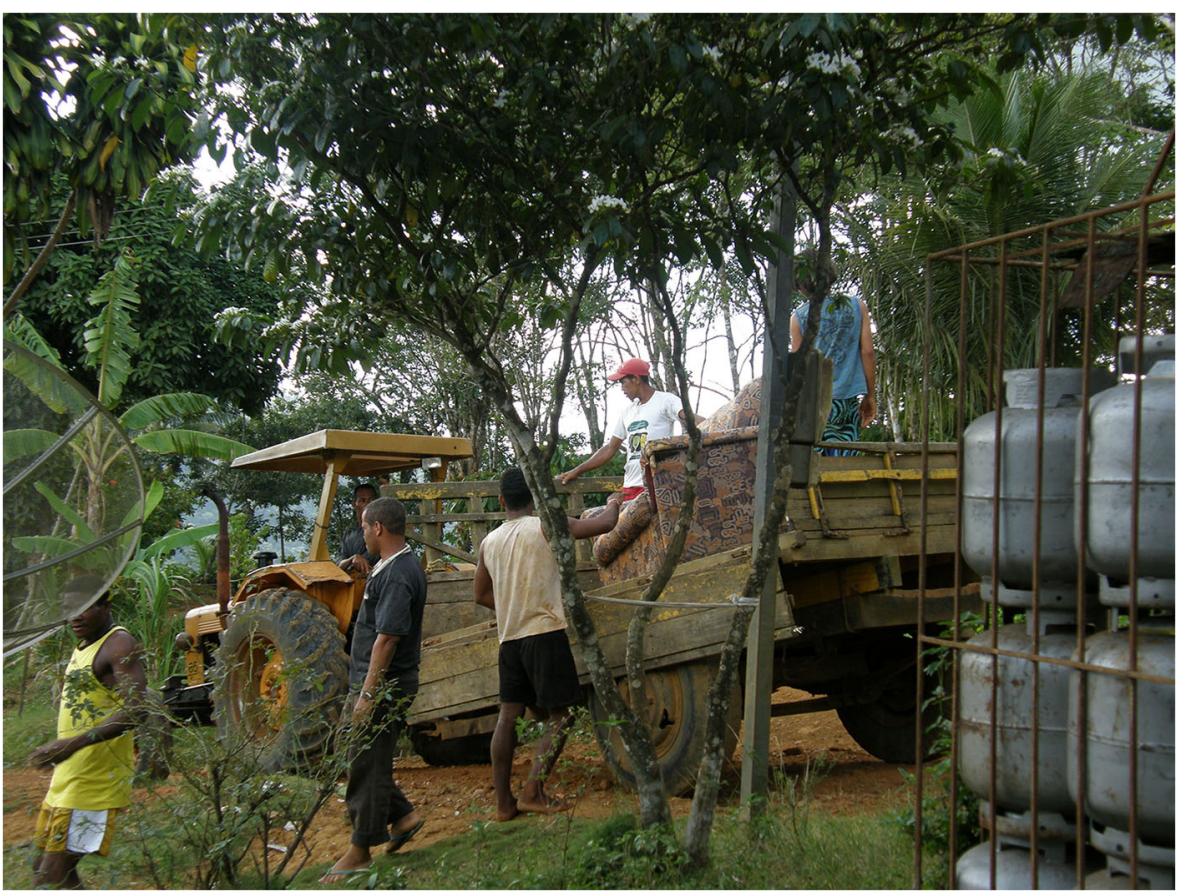

Fig. 6 Plantation transport helping a squatter family move. March 17, 2010. Photo by Jonathan DeVore

that variously occurred among squatters and their neighbors, including local plantations, most of which were informally recorded over 22 months between 2009 and 2010. In different degrees and measures, local squatters and plantation managers provided for one another according to their different needs and abilities to share.

Through acts of sharing and exchanging plants, labor, and various other resources, local squatter families achieve several outcomes. First, as their plants grow and mature, they further generalize the availability of plant materials that can be objects of future exchanges with and distributions to other people. Second, unlike cultivating impermanent annual crops, shared seeds, seedlings, and cuttings eventually grow into durable trees and perennials that substantially transform local communities' capacities for social and material (re)production. Third, by cultivating a diverse and living assortment of trees and other perennials - all "root goods"local squatter families further consummate and secure their claims to land. Like an inverse image of Woodburn's egalitarian sharing that dissolved property, people in these squatter communities leveled social hierarchies, but they did so by democratizing property for all. By contrast with those forms of sharing that merely replicated and reaffirmed the unequal status of participants at the outset, the sharing of long-lived plants transformed both social and biophysical landscapes in ways such that people emerged - together with their trees - as reconstructed subjects.

\section{Conclusion}

Although the redistribution of land that occurred in the 1990s was powerful and meaningful for hundreds of local families, it was also limited, as it did not end problems of landlessness 


\begin{tabular}{|c|c|c|}
\hline Parties \& Directionality & Object Shared & Durability of Object \\
\hline Landless family $\rightarrow$ Commons & Cashew trees & Permanent (perrenial plant) \\
\hline Landless & Medicinal & Impermanent (annual plant) \\
\hline Landless family $\rightarrow$ Squ & efrigerato & mpermanent (tool use) \\
\hline Merchant $\rightarrow$ Rural residents & Ride-share (carona) & Impermanent (transportation) \\
\hline Plantation $\rightarrow$ Landless family & Lumber & Permanent (building material) \\
\hline Plantation $\rightarrow$ Squatter & Banana rhizomes & Permanent (perrenial plant) \\
\hline $\mathrm{n} \rightarrow$ Squatter & Cacao & Impermanent (consumable food) \\
\hline Plantation - & Caca & Permanent (perrenial plant) \\
\hline Plant & Clove harvest & Impermanent (crop for sale) \\
\hline Plant & Electrical ho & Permanent (infrastructure) \\
\hline Plantation $\rightarrow$ Sq & Gas-powered blower & Impermanent (tool use) \\
\hline & Stee & Permanent \\
\hline Plantatio & Trac & Impermanent (transporta \\
\hline & Trac & Impermaner \\
\hline Plantation & Water & Permanent (infrastruct \\
\hline $\mathrm{Ru}$ & (vegetable; Sechium edule) & Impermane \\
\hline Rural resident $\rightarrow$ Squatter & tic labor & Impermanen \\
\hline us driver & $a_{0}$ & Imperman \\
\hline Squatter $\rightarrow$ Lanc & hizomes & [Variety u \\
\hline Squatter $\rightarrow$ Lanc & Ban & Impermane \\
\hline atter $\rightarrow$ Lan & Fire & Imperman \\
\hline Squatter $\rightarrow$ Lanc & Ros & Permanent \\
\hline Squatter $\rightarrow$ Mer & & \\
\hline D1tor & $I_{2}$ & fuel) \\
\hline$M \longrightarrow 1$ 1an & & ane \\
\hline atter $\rightarrow$ Plan & $\mathrm{R}$ & Impermane \\
\hline atter $\rightarrow$ Plantat & a seeds & $\mathrm{Pe}$ \\
\hline atter $\rightarrow$ Rural resident & $\mathrm{F}$ & Imp \\
\hline ter $\rightarrow$ Rur & $\mathrm{Rc}$ & $\mathrm{Pe}$ \\
\hline Squatter $\rightarrow$ Squatter & B & Imp \\
\hline er & $\mathrm{B}$ & \\
\hline Squatter $\rightarrow$ Squatter & B & Per \\
\hline atter $\rightarrow \mathrm{S}$ & es & $\mathrm{Pe}$ \\
\hline Squatter $\rightarrow$ Squatter & izo & nial plant) \\
\hline ter $\rightarrow$ & & {$[\mathrm{V}$} \\
\hline $\mathrm{er} \rightarrow$ & & \\
\hline ter $\rightarrow$ & $\mathrm{Cac}$ & $\mathrm{Pe}$ \\
\hline $\mathrm{Sc}$ & ngs for grafting & $\mathrm{Pe}$ \\
\hline$s_{0}$ & $I_{0}$ & $\mathrm{P}$ \\
\hline $\mathrm{Sq}$ & & In \\
\hline & uliflora & Pel \\
\hline Sc & Is (Syzygium jambos) & Per \\
\hline & & \\
\hline $\mathrm{er} \rightarrow \mathrm{s}$ & ds & Per \\
\hline $\mathrm{S}$ & seeds & \\
\hline $\mathrm{er} \rightarrow \mathrm{T}$ & & ant) \\
\hline & & \\
\hline & & olant) \\
\hline & & \\
\hline Town resident $\rightarrow$ Squatter & Rose cuttings for planting & Permanent (pe \\
\hline
\end{tabular}

Fig. 7 Fifty acts of sharing among squatters and other diverse parties from 2009 to 2010

and poverty among the region's remaining plantation workers. Subsequent redistributive land reform projects in the region have proceeded more slowly, and now face the regressive politics and policies of Brazil's current right-wing administration. 
Nonetheless, the redistribution and democratization of meaningful control of land, rather than mere access to land, also occasioned novel acts and expressions of sharing. The basis for the reconstructed sharing economy described above - and what makes it qualitatively different from preceding forms of sharing and sharecropping in the region-is that the parties to these exchanges have more closely approximated what Nancy Fraser (2001) calls "participatory parity." As I have suggested elsewhere, in an analysis of distributive struggles that occurred internal to several of the region's MST settlements, the achievement of participatory parity required the creation of "conditions under which no one party had the power to illegitimately disenfranchise the other, and each could support the other in shared work and political struggle" (DeVore 2015:1219). These conditions, as Fraser (2001:36) suggests, require, in part, equitable distributions of the "objective" (i.e., material) conditions that make such parity possible.

In southern Bahia, significant steps toward the achievement of participatory parity occurred through increased democratization of land ownership. As such conditions were established, or at least approximated, new and less coercive forms of social interaction emerged, including new and more egalitarian expressions of sharing. These forms of sharing were also transformative, as they helped to reconstruct and extinguish the asymmetrical form of society out of which they arose. As people shared and exchanged root goods - especially incipient trees in the forms of seeds, seedlings, and cuttings - these temporally durable plants helped consolidate the claims that landless rural proletarians made to land for themselves, as they emerged as a reconstituted peasantry. In short, the reconstructed sharing economy that arose from their land occupations propelled the ongoing reconstruction and transformation of society.

But the distinction I proposed above between transformative and replicative sharing cannot be drawn so hard and fast. While replicative forms of sharing tend to reproduce the form of society from which they arise, they may also plant seeds for a new society. Indeed, the peasant breach phenomenon, in particular, witnessed unintended social consequences of shared land through nineteenth century provision grounds, which militated against enslaved people's legal status and institutional roles as mere property objects. In this sense, as Marx learned from Hegel, even routinized, apparently replicative forms of sharing may bear the seeds of their own destruction.

Acknowledgments The author is grateful to Cristina Grasseni, Don Kalb, Kees Koonings, Patrick Neveling, João de Pina-Cabral, Naaborle Sackeyfio, James C. Scott, Lindsay Schakenbach Regele, Kalyanakrishnan (Shivi) Sivaramakrishnan, and Susana de Matos Viegas for comments and conversations about different iterations of this article, which were presented at Yale University, the University of Lisbon, Utrecht University, and Miami University of Ohio. Different stages of research and writing were supported by the Program in Agrarian Studies, Yale University; the National Science Foundation, Doctoral Dissertation Improvement Grant; the Fulbright-Hays Doctoral Dissertation Research Abroad Fellowship Program; the American Philosophical Society, Lewis and Clark Fund; the Rackham Graduate School, University of Michigan; and the Fulbright Institute of International Education.

\section{References}

Allais, Lucy. 2015. What properly belongs to me: Kant on giving to beggars. Journal of Moral Philosophy 12 (6): 754-771.

Ashcraft, Richard. 1986. Revolutionary politics and Locke's Two treatises of government. Princeton: Princeton University Press. 
Barickman, Bert J. 1991. The slave economy of nineteenth century Bahia: export agriculture and local market in the Reconcavo, 1780-1860. Ph.D. Dissertation. University of Illinois at Urbana-Champaign.

Barickman, Bert J. 1994. 'A bit of land, which they call roça': Slave provision grounds in the Bahian Recôncavo, 1780-1860. The Hispanic American Historical Review 74 (4): 649-687.

Bartels, Larry M. 2008. Unequal democracy: the political economy of the New Gilded Age. Princeton: Princeton University Press.

Benkler, Yochai. 2004. Sharing nicely: on shareable goods and the emergence of sharing as a modality of economic production. The Yale Law Journal 114 (2): 273-358.

Berlin, Ira, and Philip D. Morgan. 1991. The slaves' economy: Independent production by slaves in the Americas. London: Frank Cass.

Brandom, Robert B. 2019. A spirit of trust: a reading of Hegel's Phenomenology. Cambridge: The Belknap Press of Harvard University Press.

Cardoso, Ciro F.S. 1979. Agricultura, escravidão e capitalismo. Petrópolis: Vozes.

Cardoso, Ciro F.S. 1988. The peasant breach in the slave system: New developments in Brazil. Luso-Brazilian Review 25 (1): 49-57.

Chalhoub, Sidney. 1989. Slaves, freedmen and the politics of freedom in Brazil: the experience of blacks in the city of Rio. Slavery \& Abolition: A Journal of Slave and Post-Slave Studies 10 (3): 64-84.

Cockayne, Daniel G. 2016. Sharing and neoliberal discourse: the economic function of sharing in the digital ondemand economy. Geoforum 77: 73-82.

Cole, Andrew. 2004. What Hegel's master/slave dialectic really means. Journal of Medieval and Early Modern Studies 34 (3): 577-610.

Beltrán, Gonzalo Aguirre. 1979. Regions of refuge. Washington: Society for Applied Anthropology.

DeVore, Jonathan. 2014. Cultivating hope: struggles for land, equality, and recognition in the cacao lands of southern Bahia, Brazil. Ph.D. Dissertation. University of Michigan.

DeVore, Jonathan. 2015. The Landless invading the landless: participation, coercion, and agrarian social movements in the cacao lands of southern Bahia, Brazil. The Journal of Peasant Studies 42 (6): 1201-1223.

DeVore, Jonathan. 2016. Reflections on crisis, land, and resilience in Brazil's politics of distribution. Focaal Blog, October 6. http:/www.focaalblog.com/2016/10/06/jonathan-devore-reflections-on-crisis-land-andresilience-in-brazils-politics-of-distribution/ Accessed 15 December 2019.

DeVore, Jonathan. 2017a. Odebrecht's original sins: Another case for reparations. NACLA Report on the Americas 49 (4): 408-415.

DeVore, Jonathan. 2017b. Trees and springs as social property: a perspective on degrowth and redistributive democracy from a Brazilian squatter community. Journal of Political Ecology 24: 644-666.

DeVore, Jonathan. 2017c. Watermill. Theorizing the contemporary, Fieldsights, December 19. https:/culanth. org/fieldsights/our-electric-exchanges Accessed 15 Dec 2019.

DeVore, Jonathan. 2018. Scattered limbs: capitalists, kin, and primitive accumulation in Brazil's cacao lands, 1950s-1970s. The Journal of Latin American and Caribbean Anthropology 23 (3): 496-520.

DeVore, Jonathan. 2019. Afterword: from affirmative to transformative distributive politics. In Money from the government in Latin America: Conditional cash transfer programs and rural lives, ed. Maria Elisa Balen and Martin Fotta, 193-204. London: Routledge.

DeVore, Jonathan, Eric Hirsch, and Susan Paulson. 2019. Conserver la nature humaine et non humaine. Un curieux cas de conservation conviviale au Brésil. Revue Anthropologie et Sociétés 43 (3): 31-58.

Dodson, Kevin E. 2003. Kant's socialism: a philosophical reconstruction. Social Theory and Practice 29 (4): $525-538$.

Ferguson, James. 2015. Give a man a fish: reflections on the new politics of distribution. Durham: Duke University Press.

Flesher, Kevin M. 2006. Explaining the biogeography of the medium and large mammals in a human-dominated landscape in the Atlantic Forest of Bahia, Brazil: Evidence for the role of agroforestry systems as wildlife habitat. Ph.D. Dissertation. Rutgers University.

Foster, John Bellamy. 2015. Late Soviet ecology and the planetary crisis. Monthly Review 67 (2): 1-20.

Fraga Filho, Walter. 2016. Crossroads of freedom: slaves and freed people in Bahia, Brazil, 1870-1910, trans. Mary Ann Mahony. Durham: Duke University Press.

Fraser, Nancy. 1995. From redistribution to recognition? Dilemmas of justice in a 'postsocialist' age. New Left Review 1 (212): 68-93.

Fraser, Nancy. 2001. Social justice in the age of identity politics: redistribution, recognition, and participation. In Redistribution or recognition? A political-philosophical exchange, ed. Nancy Fraser and Axel Honneth, 7109. London: Verso.

Genovese, Eugene D. 1974. Roll, Jordan, roll: the world the slaves made. New York: Pantheon Books.

Harvey, David. 2003. The new imperialism. Oxford: Oxford University Press. 
Hegel, Georg Wilhelm Friedrich. 1977. [1807]. Phenomenology of spirit, trans. A.V. Miller. Oxford: Clarendon Press.

Helfrich, Silke, and David Bollier. 2015. Commons. In Degrowth: a vocabulary for a new era, ed. Giacomo D’Alisa, Federico Demaria, and Giorgos Kallis, 75-78. New York: Routledge.

Kant, Immanuel. 1999. [1797]. Metaphysical elements of justice: part one of The metaphysics of morals, trans. John Ladd. Indianapolis: Hackett Publishing Company, Inc.

Ladd, John. 1999. Translator's introduction. In 1999[1797]. Metaphysical elements of justice: part one of The metaphysics of morals, trans. John Ladd, ed. Immanuel Kant, xv-liv. Indianapolis: Hackett Publishing Company, Inc.

Leeds, Anthony. 1957. Economic cycles in Brazil: The persistence of a total-culture pattern. Cacao and other cases. Ph.D. Dissertation. Columbia University.

Locke, John. 1824. ([1691]). The works of John Locke in nine volumes. Volume 4: economic writings and Two treatises of government. London: Printed for T. Longman, B. Law and Son.

Mahony, Mary Ann. 1996. The world cacao made: Society, politics, and history in southern Bahia, Brazil, 1822-1919. Ph.D. Dissertation. Yale University.

Malm, Andreas, and Alf Hornborg. 2014. The geology of mankind? A critique of the Anthropocene narrative. The Anthropocene Review 1 (1): 62-69.

Martin, Chris J. 2016. The sharing economy: a pathway to sustainability or a nightmarish form of neoliberal capitalism? Ecological Economics 121: 149-159.

Marx, Karl. 1976. [1867]. Capital: a critique of political economy. Vol. Volume 1. New York: Penguin books.

Mintz, Sidney W. 1974. Caribbean transformations. Baltimore: Johns Hopkins Press.

Moon, David. 1999. The Russian peasantry, 1600-1930: the world the peasants made. London: Longman.

Moore, Jason W. 2017. The Capitalocene, part I: on the nature and origins of our ecological crisis. The Journal of Peasant Studies 44 (3): 594-630.

Moore, Jason W. 2018. The Capitalocene, part II: accumulation by appropriation and the centrality of unpaid work/energy. The Journal of Peasant Studies 45 (2): 237-279.

Morton, Gregory Duff. 2018. Neoliberal eclipse: Donald Trump, corporate monopolism, and the changing face of work. Dialectical Anthropology 42 (2): 207-225.

O’Dwyer, Eliana Cantarino. 2008. Carteira assinada: 'Tradicionalismo do desespero'? In Processos de constituição e reprodução do campesinato no Brasil: Formas tuteladas de condição camponesa, volume 1, ed. Delma Pessanha Neves and Maria Aparecida de Moraes Silva, 233-246. São Paulo, SP: Editora UNESP.

Orser Jr, Charles E. 2012. Why the Gilded Age...and why now? International Journal of Historical Archaeology 16 (4): 623-633.

Pereira, Anthony W. 1997. The end of the peasantry: the rural labor movement in northeast Brazil, 1961-1988. Pittsburgh, PA: University of Pittsburgh Press.

Pereira, J.L., A. Ram, J.M. de Figueiredo, and L.C.C. de Almeida. 1989. Primeira ocorrência de vassoura-debruxa na principal região produtora de cacau do Brasil. Agrotrópica 1 (1): 79-81.

Redding, Paul. 2012. The role of work within the processes of recognition in Hegel's idealism. In New philosophies of labour, ed. Nicholas H. Smith and Jean-Philippe Deranty, 41-62. Leiden: Brill Press.

Rocha da Silva Egnaldo. 2018. Campesinato negro: Conflito e luta pelo acesso e permanência na terra no Baixo Sul da Bahia (1950-1985). Ph.D. Dissertation. Pontifícia Universidade Católica de São Paulo.

Schwartz, Stuart B. 1977. Resistance and accommodation in eighteenth-century Brazil: the slaves' view of slavery. Hispanic American Historical Review 57 (1): 69-81.

Schwartz, Stuart B. 1992. Slaves, peasants, and rebels: reconsidering Brazilian slavery. Urbana: University of Illinois Press.

Scott, James C. 2009. The art of not being governed: an anarchist history of upland Southeast Asia. New Haven: Yale University Press.

Shanin, Teodor, ed. 1983. Late Marx and the Russian road: Marx and 'the peripheries of capitalism'. New York: Monthly Review Press.

Silva, Eduardo. 1989. A função ideológica da brecha camponesa. In Negociação e conflito: A resistência negra no Brasil escravista, ed. João José Reis and Eduardo Silva, 22-31. São Paulo: Companhia das Letras.

Soares de Sousa, Gabriel. 1879. [1587]. Tratado descriptivo do Brasil em 1587. Rio de Janeiro: Tipografia de João Inácio da Silva.

Sypnowich, Christine. 2006. Begging. In The egalitarian conscience: essays in honour of G. A. Cohen, ed. Christine Sypnowich, 177-194. Oxford: Oxford University Press.

Taylor, Charles. 1975. Hegel. Cambridge: Cambridge University Press.

Thompson, E.P. 1993. Custom, law and common right. In Customs in common, 97-184. London: Penguin Books. 
Tosta Filho, Ignácio. 1948. Plano de ação econômica para o Estado da Bahia. Secção B do volume 2. Salvador, Bahia: Instituto de Cacau da Bahia.

Waldron, Jeremy. 1988. The right to private property. Oxford: Clarendon.

Waldron, Peter. 2007. Governing Tsarist Russia. New York: Palgrave Macmillan.

Watkins, Case. 2015. African oil palms, colonial socioecological transformation and the making of an AfroBrazilian landscape in Bahia, Brazil. Environment and History 21 (1): 13-42.

Widlok, Thomas. 2005. Introduction. In Property and equality. Volume 1: Ritualisation, sharing, egalitarianism, ed. Thomas Widlok and Wolde Gossa Tadesse, 1-17. New York: Berghahn.

Widlok, Thomas. 2017. Anthropology and the economy of sharing. New York: Routledge.

Wittgenstein, Ludwig. 1953. Philosophical investigations. Oxford: Basil Blackwell.

Woodburn, James. 1982. Egalitarian societies. Man 17 (3): 431-451.

Publisher's note Springer Nature remains neutral with regard to jurisdictional claims in published maps and institutional affiliations. 